\title{
The geopolitical ecology of New Caledonia: territorial re-ordering, mining, and Indigenous economic development
}

\author{
Simon P.J. Batterbury ${ }^{1}$ \\ Matthias Kowasch \\ Séverine Bouard \\ University of Melbourne, Australia and Lancaster University, UK \\ University College of Teacher Education Styria, Austria \\ New Caledonian Agronomic Institute, New Caledonia
}

\begin{abstract}
In the French Pacific territory of New Caledonia, conflict and difference between Indigenous Kanak people and European settlers has existed at least since the 1850s. We interrogate the geopolitical ecology of these islands, which is deeply wedded to natural resource extraction, and is instrumentalized in political debate, power struggles, conflict, and the mining sector. Territoriality, including changes to political borders and access to land, has promoted the interests of the key actors in shaping the future of the islands. Violence in the 1980s was followed by the Matignon Accords (1988) and three provinces were established (North, South, Loyalty Islands). The South Province is governed by a party loyal to France, and the others are in the hands of the Indigenous Kanak independence movement seeking full decolonization and independence. The strengthened regional autonomy that emerged from the creation of provinces has permitted the Kanak-dominated ones to control certain political competencies as well as to guide economic development much more strongly than in other settler states, notably through a large nickel mining project in the North Province. Provincialization has not diminished ethnic divisions as French interests hoped, as signaled by voting in the close-run but unsuccessful 2018 referendum on independence from France. We explore the ironies of these efforts at territorial re-ordering, which are layered on significant spatial and racial disparities. Re-bordering has enabled resurgence of Kanak power in ways unanticipated by the architects of the Accords, but without a guarantee of eventual success.
\end{abstract}

Key Words: New Caledonia, geopolitical ecology, politics of mining, decolonization, Kanak identity

\section{Résumé}

Dans le territoire de la Nouvelle-Calédonie du Pacifique français, les conflits et les différences entre les peuples autochtones kanaks et les colons européens existent au moins depuis les années 1850. Nous interrogeons l'écologie géopolitique de ces îles, profondément ancrée dans l'extraction des ressources naturelles, instrumentalisée dans le débat politique, les luttes de pouvoir, les conflits et le secteur minier. La territorialité, y compris les modifications des frontières politiques et l'accès à la terre, a promu les intérêts des acteurs clés dans la construction de l'avenir des îles. La violence des années 1980 a été suivie par les accords de Matignon (1988) et la création de trois provinces (Nord, Sud, îles Loyauté). La province du Sud est gouvernée par un

\footnotetext{
${ }^{1}$ Dr. Simon Batterbury, Associate Professor, School of Geography, University of Melbourne, Australia and Visiting Professor, LEC, Lancaster University, UK. Email: simonpjb "at" unimelb.edu.au. Dr. Matthias Kowasch, Professor, University College of Teacher Education Styria, Graz, Austria. Email: matthias.kowasch "at" phst.at. Dr. Séverine Bouard, senior research fellow, IAC (Institut Agronomique néo-Calédonien), Centre de Recherche Nord Thierry Mennesson, Pouembout, New Caledonia. Email: Email: bouard "at" iac.nc. Acknowledgements: Thanks to Prof. Joy Porter for comments on a draft, Prof. Casey Walsh for comments and accepting the article, and the two referees for extensive reviews. Research was funded by the CNRT, IAC and the French Embassy in Australia over several years. We are also deeply thankful to the Kanak communities and other interviewees who welcomed us and who helped us with information and support.
} 
parti loyaliste, c'est-à-dire attaché à la République française et contre l'indépendance, et les deux autres sont gérées par le mouvement indépendantiste kanak qui cherche à obtenir une décolonisation et une indépendance complètes. L'autonomie régionale renforcée qui a résulté de la création des provinces a permis aux Kanak de contrôler certaines compétences politiques telles que le développement économique beaucoup plus fortement que dans d'autres États colonisateurs, notamment grâce à un projet d'extraction et de transformation de nickel d'envergure international en province Nord. La provincialisation n'a pas atténué les aspirations indépendantistes et les divisions ethniques autant que l'espéraient les intérêts français, comme l'a montré le vote lors du référendum de 2018 sur l'accès à la pleine souveraineté, au résultat très serré mais sans succès. Nous explorons l'ironie de ces efforts de réorganisation territoriale, qui reposent sur d'importantes disparités spatiales et raciales. Redessiner les frontières et compétences provinciales a offert un espace d'expression du pouvoir kanak d'une manière inattendue pour les architectes des accords, mais sans garantie de succès.

Mots-clés : Nouvelle-Calédonie, écologie politique, politiques minières, décolonisation, identité Kanak.

\section{Resumen}

En el territorio francés del Pacífico de Nueva Caledonia, el conflicto y la diferencia entre el pueblo indígena canaco y los colonos europeos ha existido al menos desde la década de 1850. Cuestionamos la ecología geopolítica de estas islas, que está profundamente ligada a la extracción de recursos naturales, además de actualizarse en el debate político, las luchas de poder, los conflictos y el sector minero. La territorialidad, incluidos los cambios en las fronteras políticas y el acceso a la tierra, ha promovido los intereses de los actores clave en la configuración del futuro de las islas. La violencia en la década de 1980 fue seguida por los Acuerdos de Matignon (1988) y se establecieron tres provincias (Norte, Sur y las Islas de la Lealtad). La provincia del Sur está gobernada por un partido leal a Francia, y los demás están en manos del movimiento independentista indígena canaco que busca la descolonización e independencia totales. La autonomía regional fortalecida que surgió de la creación de provincias ha permitido que las dominadas por los canacos controlen ciertas competencias políticas. También han podido orientar el desarrollo económico con mucha más fuerza que en otros estados colonos, en particular a través de un gran proyecto de extracción de níquel en la provincia del Norte. La provincialización no ha reducido las divisiones étnicas como esperaban los intereses franceses. Esto fue evidente en un referéndum de 2018 sobre la independencia de Francia, que fue cerrado pero infructuoso. Exploramos las ironías de estos esfuerzos de reordenamiento territorial, que se superponen a importantes disparidades espaciales y raciales. La reorganización política de las islas ha permitido el resurgimiento del poder canaco en formas inesperadas por los arquitectos de los Acuerdos, pero sin garantía de éxito eventual.

Palabras clave: Nueva Caledonia, ecología geopolítica, política minera, descolonización, identidad canaca.

\section{Introduction}

Imagine if almost half the population of Australia, New Zealand, Canada or the United States were indigenous today, as the Kanak are in New Caledonia. How might it affect their "national" politics? (Chappell 2003: 189)

In the light of this important question from historian David Chappell, it is important to remember that struggles for Indigenous recognition and justice across the world take many different forms. Battles for sovereignty in countries like Australia involve an Indigenous population that soon became a minority, suffered at the hands of increasing numbers of settlers over time, and was progressively alienated from territory as well as being denied equal rights. In the case of Kanaky/New Caledonia ${ }^{2}$ (Nouvelle-Calédonie) in the Pacific, the Indigenous population were a numerical majority for over a century after French colonial rule, and this has, along with a complex range of economic and political factors, led to a very different set of geopolitical outcomes.

\footnotetext{
2 The majority of Indigenous Kanak people call their lands "Kanaky", instead of the official name "New Caledonia" or "Nouvelle-Calédonie" Moreover, the Nouméa Accord signed in 1998 included a provision that a new country name should be agreed on. Kanaky-New Caledonia has been proposed, but political authorities have not yet decided on a new name. We use the term "Kanaky/New Caledonia" in this article to reflect the variance in thinking.
} 
The particularity of New Caledonia's history, and its importance in debates about territoriality and bordering is that in recent decades, the Indigenous Kanak minority have been able to turn natural resource wealth some way to their own advantage. They have advanced their economic position somewhat further than many other Indigenous groups in settler states around the world. This process has begun to involve capturing revenues from extractive industries, and it has not been without costs, not least to the unique ecology of their islands. This has been despite the presence of a colonial regime that, for well over a century, operated policies that actively discriminated against the Indigenous population, overriding its territory and culture to secure land and lucrative natural resources. In this article we explore key aspects of Kanaky/New Caledonia's geopolitical history, with its strong link to natural resource extraction (mainly of nickel ores), in the light of debates over territoriality and geopolitical ecology. ${ }^{3}$ This historical analysis reveals how there have been episodes of struggle and attempted coexistence between Kanak people, European settlers, and other residents. We outline in detail the complexities of Kanaky/New Caledonia's experiences with colonization and decolonization, which have culminated in recent years with turning Indigenous control of territory into economic development activity based on natural resource wealth. In the lineage of conflict around the colonial status of the islands, the creation and alteration of political borders has played a role in reshaping ethnic and socio-economic boundaries in colonial but also in postcolonial contexts.

We are particularly concerned with mining-led development and geopolitical contests. We argue that the geopolitical importance of the large nickel sector on the main island has colored the decolonization process - it is the central element of a New Caledonian geopolitical ecology. This also has some significance for debates in social science about strategies for resistance based on alternative ontologies - the Kanak leadership have used "... political strategies to defend or re-create worlds that retain important relational and communal dimensions, particularly from the perspective of today's multiple territorial struggles" (Escobar 2018). We start with a brief summary of colonial and postcolonial histories, including a focus on resource extraction. Then, we outline rebalancing policies that have created and modified territorial boundaries in Kanaky/New Caledonia. These are strongly linked to development efforts in the North Province, and to mining and land access. Some broader geopolitical and economic reflections precede the conclusions.

\section{Ecology, and colonial and postcolonial histories}

New Caledonia is a settler economy of 271,407 inhabitants (census 2019; ISEE 2020). It remains one of France's few 'settler economies', although there has been some devolution of powers since the 1980s (Kowasch et al. 2015). It has had a relatively troubled history of conflict between francophone settlers and Kanak peoples ${ }^{4}$, since the mid-1800s. The 1980s brought the islands to global attention when many Kanak, particularly youth, were in open revolt against the French state and the population of white settlers (Winslow 1995). Since that time several post-conflict political accords and peace agreements were signed between the leadership of both groups and the French government. New Caledonia or Kanaky, as Kanak call their homeland, remains on the UN's list of Non-Self-Governing Territories, as a 'collectivité sui generis' French territory - residents still have French citizenship. In 2018, there was an unsuccessful referendum on full independence from France, but the Nouméa Accord, signed in 1998 by representatives of the independence movement, pro-France parties and the French government provides opportunities for a second and eventually a third referendum. The next independence vote will be on 6 October 2020, and residents have a further opportunity to re-define their relationship with France, and also their participation in the Pacific region (Fisher

\footnotetext{
${ }^{3}$ Our methodology includes numerous local surveys, long periods of residence, two $\mathrm{PhD}$ studies, and numerous research projects (partly financed by New Caledonian CNRT funds), and analysis of New Caledonian materials, literature and archives, all over the last 15 years. The bibliography contains references to some of our studies.

${ }^{4}$ The Melanesian inhabitants of New Caledonia have 28 languages, and distinct cultures. The unifying term Kanak, which they broadly accepted from the 1970s to demonstrate their historical similarities and unity, comes from the "Hawaiian word for person, kanaka, which travelled around the Pacific on trade ships and plantations." By contrast, "The white settlers ... became known as Calédoniens (later Caldoches), from British explorer James Cook's decision to name the main island of Grande Terre after Scotland (the old Caledonia)." (Chappell 2003: 188).
} 
2021). Of course, an eventual political independence would redefine the islands' geopolitical status and their political boundaries.

The ecology of the largest island, Grande Terre (approx. $450 \mathrm{~km} \times 60 \mathrm{~km}$ ), is unique, although the environmental politics surrounding its protection are tense, given a large nickel mining sector (Rodary 2021). It consists of plains falling to the ocean on the west side, with short lateral river catchments. It has a mountain chain to the center and the east falls to the ocean with fewer beaches and bays, on a coast that is rainier and less accessible by land than the western side. The islands as a whole have the world's highest plant endemism $(3,380)$, but there were no land mammals remaining in immediate precolonial times other than a flying fox (Pteropus vetulus) and bats. While there is an endangered virtually flightless bird, the Cagou (Rhynochetos jubatus), larger ones (eg Sylviornis neocaledoniae) had already been hunted to extinction before European arrival (Kier et al. 2009: 9325; Jaffre et al. 1997). Gondwanan flora from the late Cretaceous period still exists. Grande Terre also has around $25 \%$ of the world's known nickel reserves exploited in around 20 opencast and mountaintop mines (Figure 1), and the world's second longest coral reef $(1,100 \mathrm{~km})$, part of which is classified as a UNESCO world heritage site (UNESCO 2020). Nickel mining has impacted runoff, river systems, reefs, soils, and air quality for decades, but environmental impacts (which include dust, water abstraction and pollution, and formerly, spillover of tailings into river and reef ecologies and affecting sedimentation patterns) are better controlled today than in the past (Rodary 2021).

Around $40 \%$ of the total population today are Kanak (ISEE 2020), and they are dominant on the outer islands and the north of Grande Terre. Material evidence - pottery shards from the Lapita site in northern Grande Terre - show they were present around 1,500 BC. Kanak operated a clan-based patrilocal society with livelihoods based largely on tropical agriculture, some hunting and fishing, and island (and initially, interisland) trade. Control of territory and land has major significance for the clans, whose identity was registered as an itinerary, as a series of places where families passed through and lived (Naepels 1998, 2006; Kowasch et al. 2015). There were distinctive regional linguistic groupings, and small-scale inter-clan warfare was frequent. Since formal colonization by France in 1853, more serious racial conflict and land disputes became common between European settlers and the Indigenous Kanak clans. "Constant military expeditions" (Saussol 1988), armed conflicts and battles went on for many decades, and Kanak resistance was met frequently with imprisonment, displacement and genocides (Poady et al. 2021).

Anglican and Marist Catholic missionaries and priests, American whalers, and British sea cucumber fishermen were on the islands preceding formal annexation of New Caledonia by France in 1853 (Kowasch and Batterbury 2015). There was also a lucrative trade in sandalwood (Santalum austrocaledonicum) from the 1840s and to a lesser extent, copra. France's occupation of the islands was supported by military intervention. French settlement advanced in several stages but advanced from present-day Nouméa, culminating in expelling most Kanak from the western plains of Grande Terre, which were cleared of native vegetation, and became devoted to cattle and small farms. Over a century, the French and a few other European-origin pioneers comprising both free and penal settlers - developed their own identity as Caldoche, largely but not exclusively loyal to France and its interests. The economic success of European agriculture was limited, lacking a large internal market or facing limited export possibilities, given the remote location and relative proximity to the larger Australian economy, which also produced shared products like beef and tinned meats.

The discovery of vast nickel reserves in Grande Terre's ultramafic rocks in 1864, by the French engineer Jules Garnier, set the scene for further 'accumulation by dispossession', elevating the island's geopolitical importance. The first big mine was established on mountaintops around Thio at the East coast, opening in 1880 (Le Meur 2017). Waves of indentured and free labor came or were sent to work nickel deposits, mainly from Japan, French Indochina and the Dutch East Indies (at the time, largely Vietnamese and Javanese), resulting in some new settlement, whereas Kanak peoples had very little involvement in mining. 
Progressively, white settlement on the islands increased in volume and spatial extent. Governor Charles Guillain arrived in Kanaky/New Caledonia in 1862 to open a prison (bagne) and paved the way for a new land policy. A "dual" definition of property emerged: collective for Kanak peoples and private for Europeans. The colonial administration created Indigenous 'reserves' with a policy of cantonment (restrictions on Kanak residence on Reserves, to facilitate land dispossession elsewhere) (Bensa 1990; Merle 2000). Indigenous communities and clans were spatially relocated and their movements strictly controlled. Bensa (1990) highlights that Kanak communities were herded together on less than $10 \%$ of the total surface on Grande Terre. Only the much smaller Loyalty Islands (Figure 1) were not surrendered to colonial dispossession and suffered less oppression as a result. France's convicts, imprisoned on Grande Terre, could be released from prison at the end of their sentences to occupy farmland alienated from the Indigenous inhabitants. The historian Isabelle Merle (1993) argues that France sought to replicate the Australian settler colonialism model, if anything exceeding its harshness. This, with elements of North American treatment of Indigenous people, was unique in the French empire (Merle 2000). The "dual" land policy led to socio-economic and political boundaries and ethnic disparities that are still visible today.

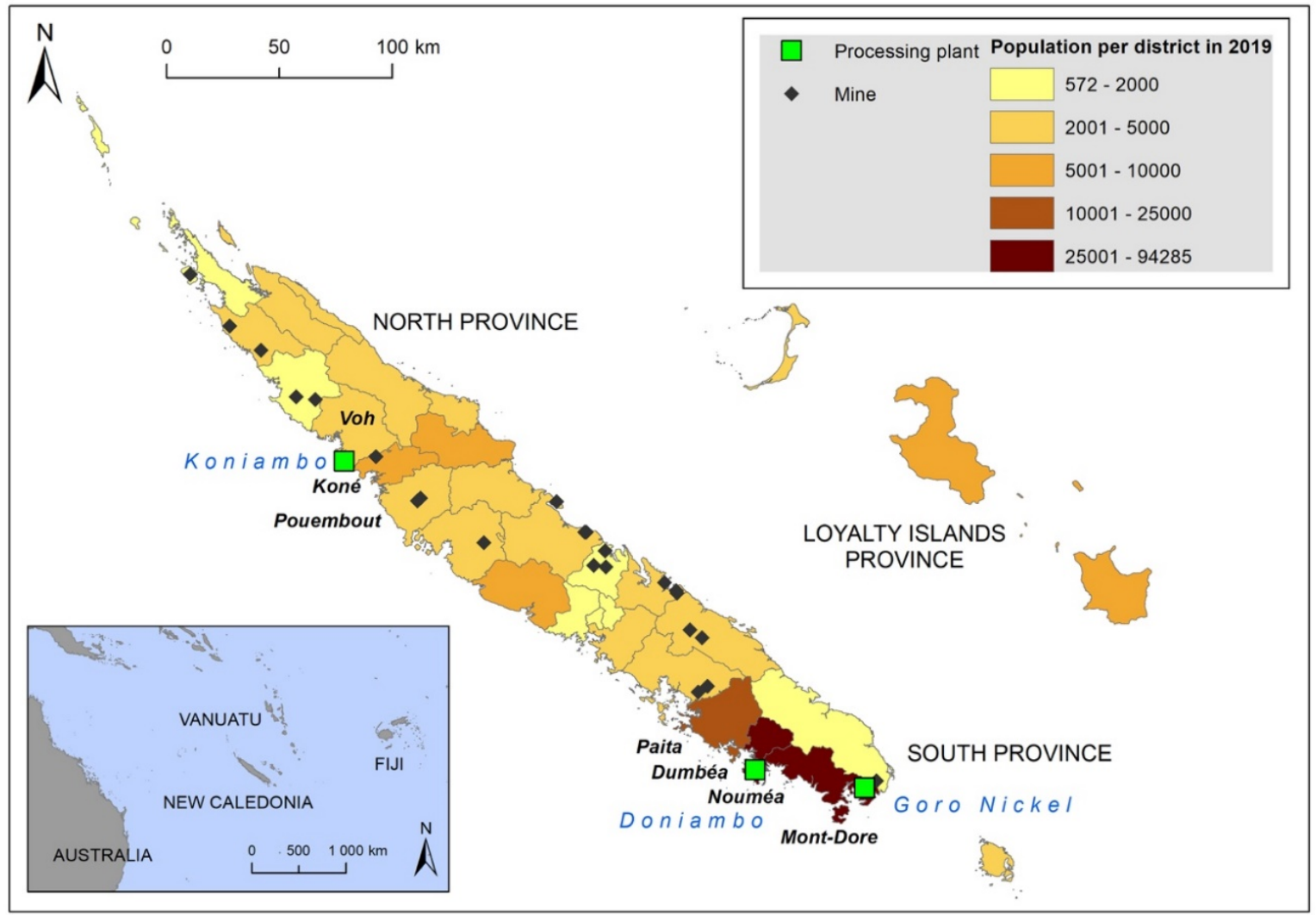

Figure 1. Nickel mining and spatial disparities in New Caledonia. (Source: ISEE 2020; cartography: Kowasch 2020)

Governance of the Kanak peoples remained brutal, culminating in the imposition of native regulations (the code de l'indigénat) in 1887 (Merle and Muckle 2019). The code de l'indigénat, designed in Algeria and extended to the majority of French colonies, was applied rigorously in Kanaky/New Caledonia until 1946 (Merle 2013). It applied to Kanak, together with contract workers from neighboring islands or Asia (except 
Japanese who remained "free", because they were protected by their government). The regulations included racist policies, forced labor, reduced mobility (Kanak people were not allowed to leave the reserves without permission from the colonial administration), imprisonment without trial, a head tax, and lack of access to services and citizenship (Robertson 2021). Kanak resistance escalated over time against the loss of territory and ancestral land, their forced relocation, and endemic discrimination. There were three major periods of violence between settlers and Kanak warriors - the 1878 guerrilla war (Douglas 1991), another in 1917 and then again from 1984-1988, as described below (Paody et al. 2021). All insurrections were defeated by the superior French forces and local Kanak allies.

Meanwhile, capital from mining was quietly accumulated by a succession of French companies over more than a century, latterly dominated by SLN (Société Le Nickel, today a subsidiary of the French mining group Eramet), who established a nickel smelter called Doniambo in Nouméa in 1910, adding additional value to its mine sites (Figure 1). The smelter is operational to this day and estuarine and air pollution are still worrying (Rodary 2021). Mining's manual labor, much of it non-European, has extended for over 140 years in several large mines, but Kanak were almost never placed in management positions.

A break-point in this history was the Second World War, when up to 50,000 American, Australian and New Zealander troops were stationed on the island, most after 1942, to counter the threat from Japan. Kanak, for the first time, witnessed African Americans and other minorities working as equals with white soldiers, and partly as a result of this visible difference to local norms, the code de l'indigénat was abolished just after the war ended. This political change, combined with further growth of the nickel industry, saw a big increase in French government funds for economic development, and led to more Kanak moving to Nouméa and other towns, where they had not been allowed to live previously (Robertson 2021). Nonetheless, the first Kanak to obtain a university degree did so much later in 1962 (Chappell 2003: 192) and the first Kanak woman graduate was the writer and former politician Déwé Gorodé in the early 1970 s.

One example of development measures and the involvement of Kanak people into the market economy was the launching of coffee plantations by the colonial administration, which dated back to the 1930s. The commodity began to reach markets overseas, and it seemed to be a success. On the eve of the Second World War, coffee production peaked at 2,350 tons, of which 2,000 were exported (Leblic 2007). Nevertheless, niche agricultural and social policies like this did not reverse marginalization and the gulf between Kanak and European standards of living, services, and infrastructure remained wide (Kohler and Pillon 1988). The Second World War led to a decline of coffee, and with the rise of nickel prices in the 1960s and more lucrative job opportunities in that sector, production fell again.

Despite the lifting of the indigénat regime in 1946, some expansion of the land available to Kanak and a series of development efforts, the Kanak as a people still suffered inferior political and economic status in the post-war years until the 1970s, when their political activism began to build again. The early 1960s, when much of Africa was decolonizing, actually saw a decline of New Caledonian political autonomy in relation to France, driven by representatives of the Gaullist regime in the metropole (de Gaulle remained in the French Presidency from 1958 to 1969). This was expressed in a statutory reform in 1969 (the lois Billotte). Nickel, chromium and cobalt were defined by this law as "economically strategic resources" (nickel is used in armaments and by the aeronautic industries), and the New Caledonian municipalities were transferred to the control of the French state, ending a period of greater tolerance of local autonomy (Forrest and Kowasch 2016).

Demands for independence rose among Kanak, along with their political consciousness and understanding of their systematic marginalization, particularly when students studying in France returned to the islands after the 1968 protests there (Chappell 2003). But between 1969-1972, the so-called "first nickel boom", more than 8,000 French citizens arrived in New Caledonia for work, tipping the demographic balance (Forrest and Kowasch 2016). In-migration was supported by the French government, still aiming to increase the proportion of non-Indigenous residents. Indeed, the Kanak population were $51.1 \%$ of the total population in 1956, but 46\% by 1969 (Vivier 2009). The nickel boom - with production records reaching nearly 8 million tonnes in 1971 - was followed by a deceleration in prices and demand until the 1980s, affecting SLN and small-scale mining operations alike (Bouard et al. 2016). Thus, the fluctuation in world nickel prices disrupted the value of New Caledonia's primary export, and local employment possibilities and wages. 
The first declaration of political independence by Kanak leaders was in 1975 (Graff 2012), when Kanak organizations met in the village of La Conception and elaborated a statement for Kanak independence. In the same year, members of different independence groups (i.e. the Foulards Rouges and Groupe 1878) founded a Marxist political pro-independence party (PALIKA). But, by the 1980s the independence movement had made little headway, and despite land reform started in 1978, Kanak communities were still cut off from much of their ancestral land, except in the Loyalty Islands, which had no great commercial possibilities or European settlement, and no nickel deposits. Grande Terre had considerable mineral riches, and land cover and soil characteristics better suited for extensive agriculture. Land and sovereignty disputes were more intense there.

The ethnic divisions between Indigenous Kanak on communal land and private European settlers largely remained in place, and racial intermixing or métissage has remained limited (although present). Health, life expectancy, school outcomes and child mortality show continued disparities to this day. It was unsurprising that the decrease of local autonomy occasioned by the big nickel boom coincided with an increase in political conflict. Kanak youth, impelled by several pro-independence leaders and political parties, took up open resistance to European settlers, farmers and pro-France activists, who were in turn, backed by their own political parties (Connell 1987). For four years in the 1980s there was sabotage, roadblocks and violence, with over a hundred people killed and multiple arrests. In 1984, the independence movement re-organized when it created an umbrella party, the FLNKS (Front de Libération National Kanak et Socialiste), including PALIKA, UC (Union Calédonienne) and other political parties and groups. The civil armed struggle, euphemistically called évènements in France, was a low point in the history of the territory in the 20th century. The violent struggles resulted in attacks and in physical relocations; in particular, many European settlers in Kanakdominated North and on the West coast moved to the Nouméa metro area.

After a hostage tragedy on Ouvéa island (Loyalty Islands Province, Figure 1) in May 1988, where 25 people (19 Kanak, 4 police and 2 military personnel) were killed after human rights abuses by French army forces, the Matignon Accords led to a negotiated peace (Waddell 2008). These agreements were signed in 1988 by FLNKS and its charismatic Kanak leader Jean-Marie Tjibaou, the anti-independence party RPCR (Rassemblement pour la Calédonie dans la République) and the French government. Considerable concessions were offered by France in a 'partial decolonization.' Given the persistence of hostilities, and the distance from France, the uncompromising attitude of the French state had to change, making way for a deal that would end the violence. One outcome, which did not please some independence supporters, was the splitting of the island into three provinces (North, South and Loyalty Islands; Figure 1), making New Caledonia a small "federated state", enabling the Kanak-dominated North and Loyalty Islands Provinces to control some of their own affairs for the first time (Mathieu et al. 2016: 103). Pro-French and pro-independence parties perceived the Matignon Agreements in different ways. According to Fisher (2021), the independence side hoped that with more time they could develop the expertise and experience needed to lead an independent state. In contrast, the loyalist side hoped that economic development and a policy of spatial rebalancing (rééquilibrage) across the territory would lead the independence parties to see the benefits of remaining with France.

\section{Re-bordering and rebalancing policies as a vehicle for decolonization}

The provincialization was an internal 're-bordering' of the territory and it has led to more peaceful political relations with France. But it has also led to an economically-driven development agenda for supporters of Kanak independence. Kanak have secured substantial devolution of political power (Kowasch 2012a). They now control two out of three provinces set up under the Matignon Accords. Since 1999, the North Province has been governed by PALIKA and its charismatic leader Paul Néaoutyine, and the Loyalty Islands Province by another pro-independence party, the UC. Financially, the French State had to provide most of the money needed for the provincial authorities to operate - in effect, subsidizing their operations, but proposing that mining revenues could supplement these transfers. The North and Loyalty Islands provinces benefited from a formula that was favorable to them, receiving three quarters of the total financial allocation from France despite their low populations (Kowasch 2012b). The rebalancing policy provided by the Matignon Accords is strongly geographical and spatial, aiming to reduce spatial disparities between the North and the South of Grande Terre, although it has, of course, been resisted by Southern loyalist interests. In the North, rebalancing projects 
commenced in 1990, for example the construction of new roads linking the east and west coast through mountainous terrain (Bouard et al. 2014; Kowasch 2012b). The increased human and financial resources devoted to local development are shown by the explosion in the number of projects carried out, and greater technical support to them (Bouard et al. 2016). The budgetary allocation formula in favor of the proindependence provinces has aided this. The New Caledonian elected territorial government (the Congress, which sits in Nouméa) also gained the authority to set its budget, including taxation and allocations for territorial projects. Moreover, the Matignon agreements also served to suspend the raising of the issue of selfdetermination and a referendum on independence for a further ten-year period.

The New Caledonian economy grew from 1965-2010 averaging almost 4\% per year, greater than mainland France (Mathieu et al. 2016), but with several cycles of growth and decline, reflecting the fortunes of nickel exports. Per capita GDP growth averaged 2.3\% per year from 1990-2010, ten and fifteen times greater than that of the Pacific islands closest to New Caledonia (Fiji, Samoa and Vanuatu) and twice as high as in the French overseas departments like La Réunion and Martinique. Prices for consumer goods are high, and Kanaky/New Caledonia qualifies as a 'developed' country given its GNI per capita, life expectancy, and other measures. Nevertheless, there are still major ethnic inequalities and social-economic disparities between the provinces, and especially between Nouméa, sometimes termed the 'Paris in the Pacific' in the South Province, and the outlying regions.

New Caledonia has advanced urban primacy. The census in 2019 shows that out of a total population of 271,407, 182,341 (67.2\%) live in Greater Nouméa, which includes the municipalities of Nouméa (94,285 inhabitants), Dumbea $(35,873)$, Mont-Dore $(27,620)$ and Païta $(24,563)$ (ISEE 2020) (Figure 1). Nouméa is also economically and financially dominant. In total, $84.1 \%$ of employees in the country work in Greater Nouméa and $74.9 \%$ of the enterprises are situated in the South, where $33 \%$ of the population is European and "only" 26\% Kanak (11\% are Wallisians/Futunians ${ }^{5}$, 10\% declared belonging to multiple communities and 20\% are 'others') (ISEE 2016). The main campus of the University of New Caledonia (UNC, part of the French public system) and most secondary schools are located in Greater Nouméa, as well as most hospitals, firms, and health services. Despite rebalancing policies, the Loyalty Islands still lack formal employment opportunities, education and health services. Their part of total population decreased from $25 \%$ at the end of the $19^{\text {th }}$ century to $6.8 \%$ in 2019 (ISEE 2020; Chauvin and Gay 2012).

Paving the way for a new nickel mine and smelter in the North Province, as part of rebalancing, was a precondition of the independence movement to start negotiation for the Nouméa Accord, finally signed in 1998. The Kanak leadership, some of whom were radicalized and familiar with socialist economic ideas from their time in France (e.g. Paul Néaoutyine, today president of the North Province, has an economics degree from Lyon; Jean-Marie Tjibaou, assassinated in 1989, studied ethnology at the Sorbonne (Waddell 2008)), requested active involvement in the nickel sector. The request came notably from PALIKA and the political authorities in the North Province, whereas other independence parties such as UC or Parti Travailliste (Labour Party) pursue other paths to political independence. The Labour Party for example asserts historical rights to the New Caledonian territory, refers to the UN Declaration on the Rights of Indigenous Peoples from 2007, and believes this mandates self-determination for Indigenous Kanak people. In contrast, PALIKA leaders have very rarely been defenders of a fetishized tradition and identity politics that seeks recognition in law (Demmer and Salomon 2013; Kowasch and Merlin 2021). By contrast, their stated aim is to use mining as a geopolitical and economic engine for strategic Indigenous development, as a pathway to Kanak independence and a thriving culture.

The idea to build a nickel processing plant in the North of the country was very much seen by these leaders as part of territorial rebalancing, placing Kanak peoples in the formal economy, developing the region and towns around the mine, and therefore providing capital to enable economic emancipation from France. The

\footnotetext{
${ }^{5}$ The Territory of the Wallis and Futuna Islands is a small Pacific island group of around 12,000 people, that chose to become a French overseas collectivity (collectivité d'outre-mer) from 1961. It was once under the administration of New Caledonia. Remittances from expatriate workers in New Caledonia, primarily residing in metro Nouméa, are important to livelihoods.
} 
Koniambo project can thus be seen as an economic re-bordering of the New Caledonian territory, which we will analyze in the following section.

\section{Mining as an engine for economic 're-bordering' and development}

To build a processing plant in the North, the provincial PALIKA authorities looked for an industrial partner to supply the know-know and financial means (Pitoiset and Wéry 2008). They found the Canadian mining company Falconbridge (later acquired by Xstrata, then Glencore) and agreed on a 51/49\% shareholding model in their favor. The Koniambo nickel project was finally initiated in 1998 (under the Bercy agreement, a complex swap of mine titles, see Kowasch et al. 2015) and it comprises mountaintop open cast nickel mining, and a new smelter powered by a coal-fired power station (Figures 1,2). It was forecast to have a production capacity of 60,000 tonnes of ferronickel per year, and produced its first nickel ingots in 2013 (Kowasch 2017).

However, before the inauguration of the Konimabo smelter, another nickel processing plant began its operation: Goro Nickel in the South Province, run by the Brazilian corporation Vale (shown on Figure 1). It was in 2003 that the Canadian company Inco (later acquired by Vale) started to build a smelter at Prony Bay. It has provincial government support, but it was less implicated in geopolitical strategizing and it was violently contested by local Kanak communities before deals were struck (Kowasch and Merlin 2021). Another difference is that it uses a hydrometallurgical process that has had serious technical problems, polluting the reef and leading to long periods of shutdown. In 2020, Vale has an offer to sell the plant to the much smaller Australian company New Century, which wishes to acquire the 95\% Vale shareholding. We now return to the northern Koniambo project that is more relevant to our argument.

The construction of the Koniambo nickel smelter has been accompanied by urban development of the "VKP" region, comprising the three municipalities (Voh, Koné and Pouembout) and the smelter and industrial areas. This regional growth pole in the north of Grande Terre is the center of Grande Terre's 'rebalancing' effort, and includes ancillary businesses, retail malls, new housing, a hospital and educational and cultural services (e.g. a cinema, library, and swimming pool) (Figure 3). The overall geopolitical aim of the Northern provincial authorities is, as we have shown, to reclaim territory either as an independent nation, but if not, to demonstrate the ability of Kanak politicians to create jobs and services in the North province to counter Nouméa in the South (Kowasch 2012a).
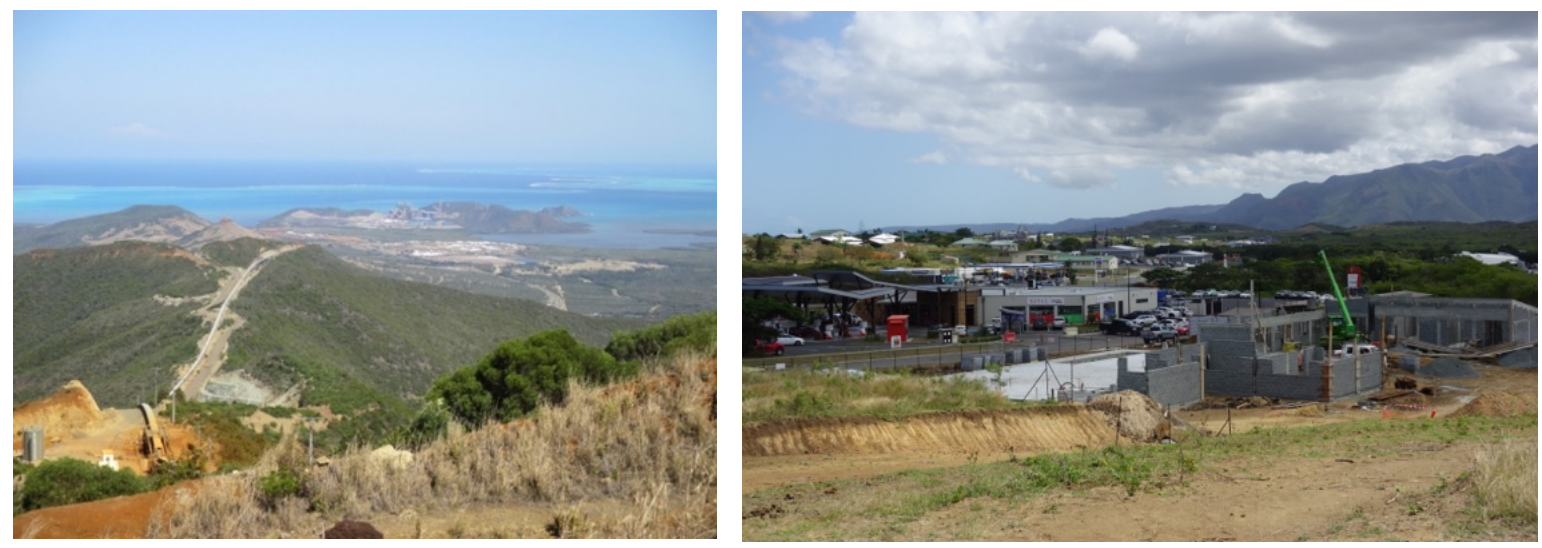

Figure 2: Koniambo project, from the mine to the smelter, with reef beyond. Source: Kowasch 2016. Figure 3: Filling station and other economic projects on customary land. Source: Kowasch 2019.

This geopolitical strategy has been termed 'leading our own development', echoing some of Jean-Marie Tjibaou's ideas for reclaiming Melanesian identity based on ancestral values (Waddell 2008). Kanak political 
leaders in the nickel-rich North Province have used their political power to achieve control over some mining development on their own terms, even if the majority of mine titles across the New Caledonian territory remain with the French company SLN. The goal is to shift and reshape economic boundaries and disparities between the north and the south and as a result to involve Kanak communities in regional "development." A majority public ownership was chosen as their strategy through the 51/49\% shareholding model. Their investment company SOFINOR (Société de Financement et d'Investissement de la Province Nord) possesses $87 \%$ of the mining company SMSP (Société Minière du Sud Pacifique), which in turn holds the 51\% shareholding in the Koniambo project. The Swiss mining giant Glencore controls the other $49 \%$ and together with SMSP they form the joint-venture KNS (Koniambo Nickel SAS) that operates the Koniambo smelter and mine.

Mineral revenues themselves represent only one source of economic benefit from mining, which also include employment, business contracts, shareholding and infrastructure development (Banks 1996). These are beginning to make their mark, creating what Bustos-Gallardo and Prieto (2019) refer to as a growing "commodity region" reliant on sales to global markets.

The strategy is risky, however, because first, Glencore financed $96.5 \%$ of the smelter construction and controls day-to-day decision-making about the future of the project. Glencore is less dependent of the success of the Koniambo project than its local partner SMSP. For the Swiss mining giant, stock market value is more important than the revenues from these particular mining operations. Secondly, revenues only flow when the nickel prices on the world market remain high. And future cashflow will be used by SMSP to reimburse Glencore and also loans from French banks. Koniambo is far from being "the world most competitive processing plant ever" as the SMSP Chairman, André Dang (sympathetic to Kanak independence), once labelled it (Nacci 2015; Pitoiset and Wéry 2008). Nacci queries the economic model behind the project, its governance and its huge cost, and it is true that it has suffered technical setbacks and diminished production since its opening. Nonetheless, the achievement of control over mineral resources by the provincial authorities is a significant win for northern and Indigenous interests. It has re-oriented control and power relationships in the sector. The pro-independence movement party FLNKS wants Kanaky/New Caledonia to control its own (mineral) resources and thus, SMSP is now eyeing up purchasing SLN's mining titles as well, if the opportunity arises. According to the so-called "nickel doctrine", the nickel industry should fuel local development of benefit to provincial citizens, not increase overseas corporate profit margins (David et al. 2016). This "doctrine" is about halting exportation of raw ores (except to nickel smelters "offshore" where local companies have majority shareholdings) and processing them in Kanaky/New Caledonia. The aim is to make sure a New Caledonian investment company eventually obtains a majority shareholding (51\%) in SLN (NC 1 ière 2015).

Winslow, writing in this journal, noted a shift in Kanak engagement with the remaining forces of colonialism and modernity in the 1990s, and this has certainly continued (Winslow 1995). The rise of the France-trained, independence-supporting, socialist left before and during the violence of the 1980s, has echoes in the current effort to create an economic growth pole in the north of Grande Terre, although some of their radical sentiments were modified by Tjibaou's more conciliatory influence (Waddell 2008). The 'development by industrialization' strategy they are pursuing is only now beginning to decelerate a little as the major infrastructure is in place (Sourisseau et al. 2016). Its success is uncertain, but the trappings of modernity, including fast communication networks and brand-new public facilities are already in place in Koné, the capital of the North Province, and surrounds.

Regional development based on the Koniambo smelter and new infrastructures in the VKP area certainly provide new opportunities for local communities including jobs, revenues, cultural facilities and new health services. But it also has negative local effects for the natural environment, during construction phases and subsequently, alongside social pathologies and problems that come with any mining operation. In addition, mining is hardly a favored strategy to guide any form of sustainable development, at a time when the world is seeking to reduce carbon emissions and, more locally, protect coral reefs and loss of biodiversity. Mining-led Indigenous development has also led to newly emerging spatial inequalities and boundaries, for example between the east and the west coast, between the extreme north and the VKP region (Kowasch et al. 2015), between villages and urbanized areas, and between the employed and the jobless. 


\section{Other "development" efforts, boundaries and political futures}

Besides the provincial reorganization that, among other things, enabled the Koniambo project, land reform has also contributed to the greater involvement of Kanak people in socio-economic development (Kowasch et al. 2015) and has reshaped ethnic and spatial boundaries between Indigenous Kanak communities and European settlers. Land reform, as we have noted, aims to restore ownership to Kanak clans, and started in 1978. It has been slow but progressive, led by the public agency, ADRAF (Agency for Rural Development and Regional Planning). ADRAF buys private land with state funds and returns it back to Kanak clans. Land claims and distribution of titles often lead to conflict and require negotiation, because different land claims overlap (Naepels 2006). ADRAF discusses competing claims with the actors involved and helps them to negotiate solutions.

The proportion of Indigenous customary land on Grande Terre increased from 10\% in the 1970s to 19.3\% in 2019 (ADRAF 2019a; Kowasch et al. 2015). Considering that the Loyalty Islands Province was always classified as "customary land", the distribution of the territory's total land area shows that $15.8 \%$ of the territory is private property and $27.4 \%$ customary land, which is inalienable, unseizable, incommutable and non-transferable. Anti-independence parties argue the land reform should be terminated, even as new claims are still being made. From the perspective of many Kanak people, the colonial theft of lands represents a loss of cultural identity, because the social identity of clans is territorial. For them, the restitution of land is still incomplete. Claims and restitution have led to cross-clan tensions, especially since some were displaced by the colonial administration and thus have lost connection to place (Kowasch et al. 2015). Legitimacy is always unfixed and non-finite (Lund and Sikor 2009) but some clans close to towns and mines have profited from relative stability by developing some of their customary land commercially, as also occurs in Canada, the US and Australia.

Urban development in the VKP region involves some customary land, encouraged by the provincial Kanak leadership (Figure 3). The construction of shopping malls, filling stations and houses around VKP is a limited commodification of customary land based on a capitalist economic system. At the same time, the absorption of customary land and Kanak communities into the urban agglomeration constitutes a shifting of (economic) borders. Kanak clans in Baco (a village close to Koné) for example have set up their own real estate companies to benefit from future lease revenues. In rural areas the redistributed land often remains unexploited, because Kanak communities do not need it for their everyday livelihoods. Because land has symbolic value in terms of identity and land legitimacy, valorization and capital accumulation are not always the main goals (Kowasch 2018).

The Nouméa Accord of 1998 stated that colonization had attacked the dignity of the Kanak people and deprived them of their identity (Mokkadem 2013) and it was this Accord that extended the date of the independence referendum further to the period of 2014-2018. Transfer of political competencies from France (except sovereign powers that include defense, foreign affairs, currency, law and order, and justice) was termed "shared sovereignty", linked to a "common destiny" (Forrest and Kowasch 2016; Mokkadem 2013). The aim was to avoid the violent struggles of the 1980s, promoting more unity across the whole territory. While for some "common destiny" is just an empty political slogan, resonating with a brief period in the 1950s where such ideas were on the table, the Accord has at least acknowledged the violence and trauma of the colonial past and officially recognized "Kanak identity", as well as strengthening the weight of Kanak customary authorities, lands and law (Gagné 2021). Moreover, Kanaky/New Caledonia has acquired new symbols of its identity, like a New Caledonian anthem.

The Nouméa Accord also reshaped mining legislation and competencies. The Organic Law, provided by the Accord, delivered competencies governing hydrocarbons, nickel, chrome and cobalt to the New Caledonian Congress, and only nuclear energy minerals (lithium, uranium and thorium) remained with France. The competence for all other resources has been given to the provinces (Gouvernement de la NouvelleCalédonie 2009).

Complex political negotiations occurred around voting eligibility in provincial elections and in the independence referendum of 2018, prefigured in the Nouméa Accord. These were drawn-out, with Kanak parties wanting to restrict the mandate of newer arrivals that could upset a delicate political balance. The 
arguments back and forth around the referendum soon became geopolitical (see Fisher 2013, 2021; Gagné 2021; Robertson 2021). Robertson (2021) highlights that the Nouméa Accord paved the way for expanding suffrage restrictions beyond the referendum alone. Electoral borders were established. Consequently, French citizens needed to have continuous residence in New Caledonia prior to 8 November 1998 (i.e. the date of the Nouméa Accord vote). Those who did not were placed on an auxiliary list until they obtained ten years of continuous residency. Exceptions were authorized for those whose residence was interrupted for valid educational, medical or professional reasons (Robertson 2021). Despite a restricted electorate, Stastny (2018) argues that the referendum does not represent a true process of decolonization. She highlights that the right of self-determination, provided by the United Nations Declaration on the Rights of Indigenous Peoples in 2007, has still not been respected. Therefore, the vote merely confirms that Kanak people are in the political minority.

The two principles of "rebalancing" and "common destiny" have made it possible to recognize and legitimize previously marginalized population groups, leading to the introduction of differentiated public policies (Bouard et al. 2014). By transferring powers to local authorities, the Nouméa Accord has responded to (although not fully met) the Kanak people's request for autonomy, while preserving and strengthening cooperation between political parties in the establishment of a relatively collegial elected government (the Congress). Nevertheless, the decolonization process is not finished yet (Gagné 2021). The first referendum on political independence of 4 November 2018 resulted in a loss for the pro-independence parties $-56.4 \%$ of the list of eligible voters chose against independence. Nevertheless, many were surprised by the relatively high level of support for independence, as a number of polls had pointed to at least $60 \%$ favoring staying with France (Calédonie 1ère 2018; cited in Fisher 2021). Figure 4 shows the few municipalities with more than an $80 \%$ vote against independence: Nouméa (with around 100,000 inhabitants the largest municipality in Kanak/New Caledonia), Poya Sud and Farino (shown in red - both have strong loyalist communities). Leblic (2018) highlighted that a number of voters of European origin actually voted in favor of independence. There will be two more opportunities to vote again on independence, the next on 6 October 2020. And the tight referendum result conceals, of course, a geopolitical ecology of struggle going back at least to the mid-1980s. ${ }^{6}$

On France's side, the current Macron presidency does not want to be forced out from a territory that contains potentially vast marine mineral reserves, since the giant marine EEZ has unknown quantities of hydrocarbons and seabed minerals. The conservatives in French politics are not keen to reshape (political) boundaries in Kanak/New Caledonia, to lose economic advantage, or to provide new models of "development" involving full political emancipation. While it cannot deny the realities of its colonial past, France has to support the sub-population that are strongly loyal to it (the $56.7 \%$ of the voters who opposed political independence in the 2018 referendum), and politicians are very aware that while retaining Kanaky/New Caledonia costs a lot of money, the territory is surrounded by anglophone island nations with stronger geopolitical and economic links to Australia, New Zealand and the USA. This is not an inviolate geopolitical concern, but France has a history of resisting other Pacific-scale geopolitical interests, including anglophone dominance and the growing power of China.

\section{Implications}

After a colonial period leading to familiar episodes of land dispossession, forced labor and genocide, what is particular in the case of Kanaky/New Caledonia is the nature of the response from the Indigenous leadership, the concessions Kanak people have already won, but also the socio-economic and cultural changes that communities have undergone. There are three concluding points to make and as we have shown, the case involves a classic territorial conflict between early colonists and Indigenous people, swayed by the aggressive assertion of francophone power and the disruptions caused to longstanding customs and lifeways. But it has now taken on new dimensions from which we can learn.

\footnotetext{
${ }^{6}$ In 2019, legislative elections saw the emergence of a new party, L'Éveil Océanien, representing the Wallisian population, and a gain of one seat for pro-independence representatives - 28 anti-independence, 26 pro-independence.
} 


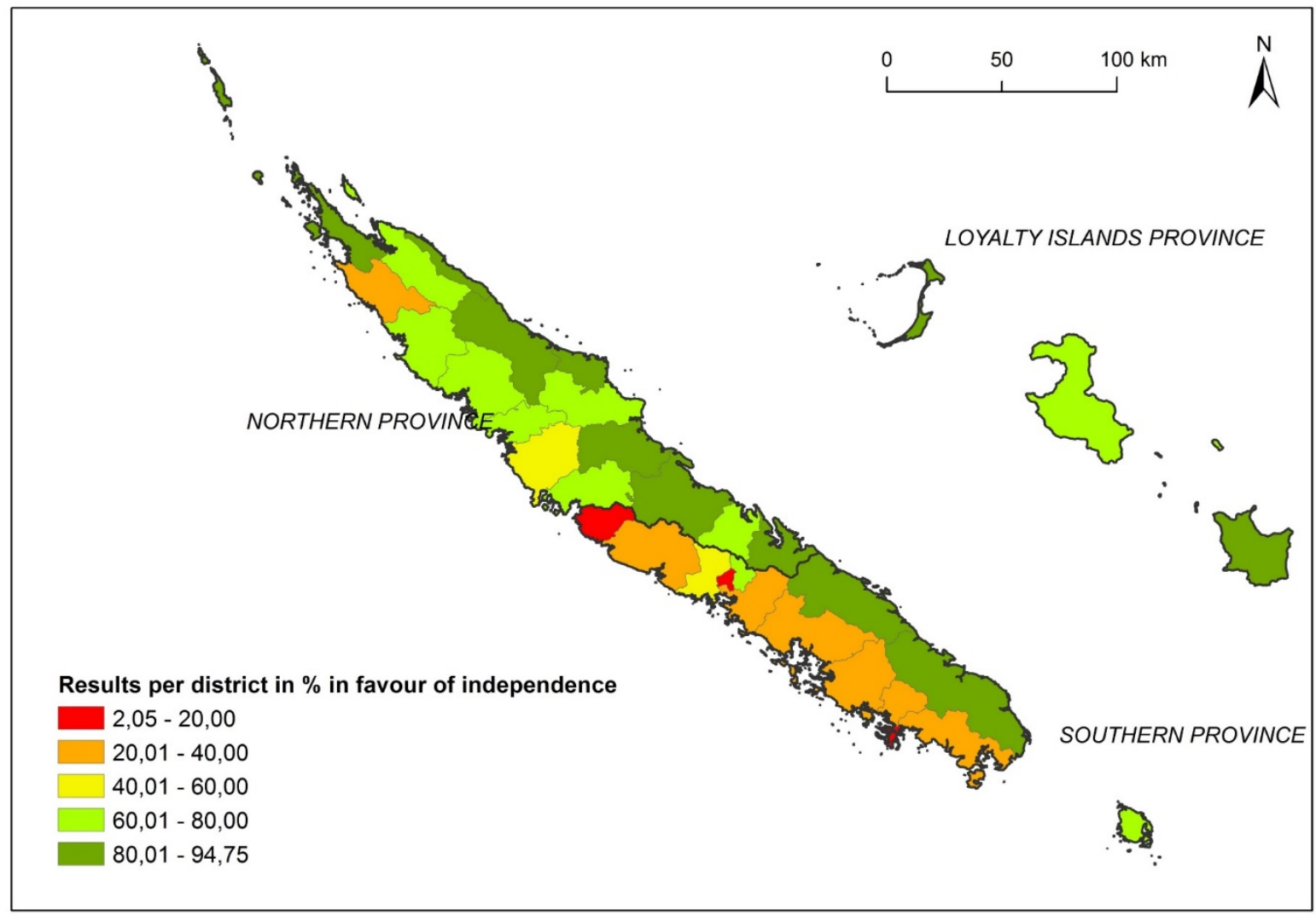

Figure 4: Referendum outcomes 2018. Source: Haut-Commissariat de la Nouvelle-Calédonie 2018. Cartography: Kowasch 2019.

The first lesson from Kanaky/New Caledonia is that territory, with an enlarged definition, is a vital concept: it includes strategic and economic interests, legal doctrines, identity, values, and there are also technical aspects to its governance and assessment (Elden 2019). If, following Lefebvre, there are "embedded social relations in spatial formations" (cited in Usher 2019), then it is clear that the provincialization of the archipelago is part of a long struggle for territory, and it has fostered the economic projects taking place in the north of Grande Terre. Kanaky/New Caledonia offers an example of "breaking out of the bounded sense of territory" (Elden 2019) impelled by a struggle for space. Despite greater provincial authority enabling economic development including the Koniambo project, the dichotomy between customary (collective) and private land remains. The recent restitution of land would perhaps have pleased Jean-Marie Tjibaou, who argued to the world that land was central to Kanak existence and worldviews (Waddell 2008). Nevertheless, the land reform started in 1978 is, from the perspective of Kanak clans, still incomplete. Land claims are still emerging, and new, negotiated "borders" exist on the margins of their returned land. Political authorities of the North Province want to imbricate customary land with urban development, but economic projects on customary land are mostly driven by investments made by non-Indigenous businesspeople, the State (e.g. a new northern campus of the University of New Caledonia) or European/Caldoche private companies. Thus, new boundaries on customary land emerge between Kanak identity and land, and "economic investment areas."

A second point is that in Kanaky/New Caledonia's complicated mix of Indigenous aspirations, conflict, and neo-colonial inequalities and control, mining is still central to the geopolitical game of decolonization and 
re-bordering. There are two factors of particular interest here. A mineral - nickel - is enlisted in circuits of capital that spread from Kanak communities to Chinese, Korean and European manufacturing plants, and to consumers and defense contractors. Nickel knows no borders. This, along with the poor environmental record of the industry, are unsurprising now that we all occupy a multi-scalar, connected world in which there is plenty of demand for scarce minerals. Nonetheless, given Kanaky/New Caledonia's position far out in the Pacific Ocean, it often escapes attention in policy circles and among scholars as a major mineral supplier, or even as a source of Indigenous revitalization and protest with ideas to contribute to ongoing struggles elsewhere (Horowitz 2012).

Thirdly, the recent history of the archipelago also shows that control by Indigenous economic interests of a huge mining project is not only possible but has partly shifted "scalar arrangements in ways that alter existing political ecologies, power relationships and conditions of access and marginality" (Miller and McGregor 2019). The control of the Koniambo project, and its spatial calibration with new housing and economic development around a northern growth pole, is quite distinctive. Indigenous customary land is now involved in economic development, which shifts economic boundaries established by the "dual" land policy. In theoretical terms, it is an assertion of Indigenous territoriality by the North Province and its commercial interests, as well as a major symbolic statement of identity and power. The Kanak leaders have, as Escobar (2018) argued for Indigenous movements more generally, taken a political path to "defend or re-create worlds that retain important relational and communal dimensions." Extended negotiations with clans resulted in the Koniambo project taking over clan territory but gaining broader economic and political power. Practically, the greater Indigenous control of mining resources has not yet resulted in a major change to political ordering the dichotomy between independence and loyalist political parties is still in place, and the second of three referenda on independence has yet to happen. Even the FLNKS does not talk of "Kanak independence" but simply "political independence" these days. Moreover, the model of economic development is a capitalist one, developed over many years by leaders familiar with Marx's transition of modes of production from feudalism to capitalism to socialism, who nonetheless value renewed recognition of Kanak identity. Indeed, this Indigenous form of geopolitical strategizing means a reliance on worldwide demand for minerals - not quite the anti-modernist, autonomous form of development that Escobar famously uncovered in Latin American communities.

\section{Conclusions}

The North Province leadership has always regretted the economic vulnerability and the environmental effects of their chosen path to economic self-reliance. In interviews and informal discussions with us, they have sometimes also regretted the ongoing influence of businesspeople from the south in their northern economic projects. A major material problem is that the partial transformation of the North Province's economy into an industrialized one based on nickel, is not sustainable in the long term, once deposits are exhausted. It is, truly, a transitional economic model. The technical difficulties encountered by Koniambo and the volatility of nickel prices already call into question the short-term growth agenda based on the nickel sector (and also benefiting from French subsidies, which could also diminish depending on politics in Paris, where budgeting is now affected by Covid-19 downturns and militancy against Macron's policies). There is still a significant debate over how to diversify economically (into other niches including tourism) but also deep questions about how, if the sui-generis territory becomes an independent nation, currency devaluation would play out in the event of losing the Franc Pacifique, a hard currency pegged to the Euro. The reinvestment of the incomes derived from nickel must certainly be treated carefully (Sourisseau et al. 2016). Furthermore, despite economic development in the north, spatial disparities are still marked, and the capital Nouméa remains the economic center of the territory. Moreover, new cash flows, jobs and subcontracting opportunities resulting from Koniambo lead to distribution conflicts within communities and clans. Discrimination and ethnic inequalities are not resolved either: Kanak people still have far less opportunity in the better-paid labor market sectors compared to Europeans (Gorohouna 2011). Racial and ethnic boundaries persist, even if there is more porosity than in the racially divided past. 
The geopolitical struggle for Kanak independence is, as Chappell (2003) noted, quite distinctive in its relationship with modernity, and its scale. It is perhaps best thought of as a form of Indigenous "resurgence" (Nirmal and Rocheleau 2019) or in the case of Koniambo, the "development of alternatives" - not really "alternatives to development" (Escobar 2016: 25). We should remember, that mining-led development in this and other resurgent contexts, like Timor Leste with its post-independence development now fueled almost exclusively by oil and gas reserves (Scheiner 2015), takes place in an increasingly carbon-constrained and warming world. The fragile local ecology is affected by the chosen geopolitical path to economic autonomy: large-scale mining. Mining, political outcomes, the ecology all have uncertain futures on these islands. They are certainly worth watching.

\section{References}

Banks, G. 1996. Compensation for mining - benefit or time-bomb? The Porgera gold mine. In R. Howitt, with J. Connell and P. Hirsch (eds.). Resources, nations and Indigenous peoples. Oxford: Oxford University Press. Pp. 223-235.

Bensa, A. 1990. Nouvelle-Calédonie - vers l'émancipation. Paris. Découvertes Gallimard.

Bouard S., J.-M. Sourisseau and B. Zenou. 2014. Intégration/ségrégation: une clé de lecture des recompositions des modèles de développement? Le cas de la Nouvelle-Calédonie. Natures, Sciences, Sociétés 22(4): 305-316.

Bouard S., J.-M. Sourisseau, V. Geronimi, S. Blaise and L. Ro'i (eds.). 2016. La Nouvelle-Calédonie face à son destin. Quel bilan à la veille de la consultation sur la pleine souveraineté ? Paris: Karthala.

Bustos-Gallardo, B. and M. Prieto. 2019. Nuevas aproximaciones teóricas a las regiones-commodity desde la ecología política. Revista de Estudios Urbano Regionales 45(135): 153-176.

Chappell, D. 2003. The Kanak Awakening of 1969-1976: radicalizing anti-colonialism in New Caledonia. Journal de la Société des Océanistes 117(2): 187-202.

Chauvin, C. and J.-C. Gay. 2012. Les îles. In J. Banvallot and J.-C. Gay (eds.). Atlas de la Nouvelle-Calédonie. Montpellier: IRD Éditions. Pp. 239-246.

Connell, J. 1987. New Caledonia or Kanaky? The political history of a French colony. Pacific Research Monograph 16. Canberra: Australian National University.

David, C., J-M. Sourisseau, S. Gorohouna and P.-Y. Le Meur 2016. De Matignon à la consultation sur l'indépendance, une trajectoire politique et institutionnele originale. In S. Bouard, J.-M. Sourisseau, V. Geronimi, S. Blaise and L. Ro'i (eds.). La Nouvelle-Calédonie face à son destin. Quel bilan à la veille de la consultation sur la pleine souveraineté? Paris: Karthala. Pp. 23-68.

Demmer, C. and C. Salomon. 2013. Droit coutumier et indépendance Kanak. Vacarme 64: 63-78.

Douglas, B. 1991. Winning and losing? Reflections on the war of 1878-79 in New Caledonia. The Journal of Pacific History 26(2): 213-233.

Elden, S. 2019. Territory/territoriality. In A.M. Orum (ed.). Wiley-Blackwell encyclopedia of urban and regional studies. Oxford: Wiley-Blackwell.

Escobar, A. 2016. Thinking-feeling with the Earth: territorial struggles and the ontological dimension of the epistemologies of the South. Revista de Antropología Iberoamericana 11(1): 11-32.

Escobar, A. 2018. Designs for the pluriverse: radical interdependence, autonomy, and the making of worlds. Durham: Duke University Press.

Fisher, D. 2021. New Caledonia's self-determination process. In M. Kowasch and S.P.J. Batterbury (eds). The geography of New Caledonia/Kanaky. Berlin/Heidelberg: Springer.

Forrest, M. and M. Kowasch 2016. New Caledonia and/or Kanaky: on the way to political independence? Pacific Geographies 46: 4-10. 
Gagné, N. 2021. Indigenous rights or national independence? Paths of self-determination in New Caledonia. In M. Kowasch and S.P.J. Batterbury (eds). The geography of New Caledonia and Kanaky. Berlin/Heidelberg: Springer.

Gorohouna, S. 2011. Dynamiques des inégalités dans un pays pluri-ethnique - Le cas de la NouvelleCalédonie. PhD Thesis in Economics. Paris: University of Paris 1 Panthéon.

Gouvernement de la Nouvelle-Calédonie. 2009. Le schéma de mise en valeur des richesses minières de la Nouvelle-Calédonie. Online: $\quad$ https://dimenc.gouv.nc/sites/default/files/download/200905_schema_mise_en_valeur_des_richesses_minieres_nc.pdf.

Graff, S. 2012. Quand combat et revendications kanak ou politique de l'État français manient indépendance, décolonisation, autodétermination et autochtonie en Nouvelle-Calédonie. Journal de la Société des Océanistes. 134(1): 61-83.

Horowitz, L.S. 2012. Translation alignment: Actor-Network Theory, resistance, and the power dynamics of alliance in New Caledonia. Antipode 44(3): 806-827.

ISEE 2020. Recensement 2019: publication des premiers résultats! Online: http://www.isee.nc/population/recensement.

ISEE 2016. Tableau de l'économie calédonienne. Nouméa: Artypo.

Haut-Commissariat de la Nouvelle-Calédonie 2018. Référendum: retrouvez ici les résultats définitifs de la consultation du 4 novembre 2018. Online: http://www.nouvellecaledonie.gouv.fr/Actualites/Referendum-Retrouvez-ici-les-resultats-definitifs-de-la-consultation-du4-novembre-2018.

Jaffre, T., P. Bouchet and J.M. Veillon 1997. Threatened plants of New Caledonia: is the system of protected areas adequate? Biodiversity and Conservation 7: 109-135.

Kier, G., H. Kreft, T. Ming Lee, W. Jetz, P. Ibisch, C. Nowicki, J. Mutke and W. Barthlott. 2009. A global assessment of endemism and species richness across island and mainland regions. Proceedings of the National Academy of Sciences 106(23): 9322-9327.

Kohler, J.-M. and P. Pillon 1986. Économie domestique et développement. L'opération Café. Nouméa: ORSTOM.

Kowasch, M. 2012a. Le développement de l'industrie du nickel et la transformation de la valeur environnementale en Nouvelle Calédonie. Journal of Political Ecology 19: 202-220.

Kowasch M. 2012b. La zone Voh-Koné-Pouembout. In J. Banvallot and J.-C. Gay (eds.). Atlas de la NouvelleCalédonie. Montpellier: IRD Éditions. Pp. 51-54.

Kowasch, M. 2017. Social and environmental transformations in the neighbourhood of a nickel mining project: a case study from Northern New Caledonia. In C. Filer and P.-Y. Le Meur (eds.). Large-scale mines and local-level politics - between New Caledonia and Papua New Guinea. Canberra: ANU Press. Pp. 99-131.

Kowasch, M. 2018. Nickel mining in northern New Caledonia - a path to sustainable development? Journal of Geochemical Exploration 194: 280-290.

Kowasch, M. and J. Merlin 2021. Conflicts and the politics of neutrality in environmental organizations facing mining projects in New Caledonia. In M. Kowasch and S.P.J. Batterbury (eds.). The geography of New Caledonia/Kanaky. Berlin/Heidelberg: Springer.

Kowasch, M., S.P.J. Batterbury and M. Neumann 2015. Contested sites, land claims and economic development in Poum, New Caledonia. Settler Colonial Studies 5(4): 302-316.

Leblic, I. 2007. Café, développement et autochtonie en Nouvelle-Calédonie. Études Rurales 180: 117-130.

Leblic, I. 2018. Vote indépendantiste en progression et excellent résultat au référendum. Mediapart 4 November. AISDPK (Association Information et Soutien aux Droits du Peuple Kanak - défend la liberté de ce peuple colonisé à s'autodéterminer). Online: https://blogs.mediapart.fr/aisdpkkanaky/blog/041118/vote-independantiste-en-progression-et-excellent-resultat-au-referendum. 
Le Meur, P.-Y. 2017. Conflict and agreement: the politics of nickel in Thio, New Caledonia. In Filer, C. and P.-Y. Le Meur (eds.). Large-scale mines and local-level politics: between New Caledonia and Papua New Guinea. Canberra: ANU Press. Pp. 157-182.

Lund, C. and T. Sikor 2009. The politics of possession. In C. Lund and T. Sikor (eds.). Access and property: $a$ question of power and authority. Oxford: Wiley-Blackwell. Pp. 1-22.

Mathieu, L., C. Couharde and G. Pestana 2016. Cadrage macroéconomique et faits stylisés. In S. Bouard, J.M. Sourisseau, V. Geronimi, S. Blaise and L. Ro'i (eds.). La Nouvelle-Calédonie face à son destin. Quel bilan à la veille de la consultation sur la pleine souveraineté? Paris: Karthala. Pp. 69-110.

Merle, I. 1993. La Nouvelle-Calédonie 1853-1920. Naissance d'une société coloniale. Les Cahiers du Centre de Recherches Historiques 11: 1-9.

Merle, I. 2000. De l'idée de cantonnement à la constitution des réserves. La définition de la propriété indigène. In Bensa, A. and I. Leblic (eds.). En pays kanak: ethnologie, linguistique, archéologie, histoire de la Nouvelle Calédonie. Paris: Éditions de la Maison des sciences de l'homme. Pp. 217-234.

Merle, I. 2013. La Nouvelle-Calédonie, terre d'expériences coloniales. Hermès 2013/1(65): 50-51.

Merle, I. and A. Muckle 2019. L'Indigénat - genèses dans l'empire français, pratiques en Nouvelle Calédonie. Paris: CNRS Éditions.

Miller F.P. and A. McGregor 2019. Rescaling political ecology? World regional approaches to climate change in the Asia Pacific. Progress in Human Geography 4(4): 663-682.

Mokkadem, H. 2013. Kanaky ou Nouvelle-Calédonie, souveraineté et independence dans l'ère post-coloniale. Revue Asylon(s) 11: 1-23.

Nacci, D. 2015. Calédonickel - natural resource curse. Caledonickel blog, Retrieved from https://caledonickel.wordpress.com/2015/10/22/natural-resource-curse/.

Naepels, M. 1998. Histoires de terres kanak. Paris: Éditions Belin.

Naepels, M. 2006. Réforme foncière et propriété dans la région de Houaïlou (Nouvelle-Calédonie). Études Rurales 117: 43-54.

NC 1ière 2015. Le FLNKS valide sa "doctrine nickel" 19 January. Online: https://la1ere.francetvinfo.fr/nouvellecaledonie/2015/01/19/le-flnks-valide-sa-doctrine-nickel222646.html

Nirmal, P. and D. Rocheleau. 2019. Decolonizing degrowth in the post-development convergence: questions, experiences, and proposals from two Indigenous territories. Environmental and Planning E: Nature and Space 2(3): 443-470.

Pitoiset, A. and C. Wéry 2008. Mystère Dang. Nouméa: Le Rayon Vert.

Poady, C.A., C. Ouetcho, A. Stastny and M. Kowasch 2021. Kanak cultural heritage on colonised, damaged lands: language, the straw and the Kanak House in Paici Cemuki and Drubea-Kapumë countries. In M. Kowasch and S.P.J. Batterbury (eds). The geography of New Caledonia/Kanaky. Berlin/Heidelberg: Springer.

Robertson, S. 2021. The citizenship dilemma in decolonising New Caledonia. In M. Kowasch and S.P.J. Batterbury (eds.). The geography of New Caledonia/Kanaky. Berlin/Heidelberg: Springer.

Rodary, E. 2021. Which environment to protect in New Caledonia? In M. Kowasch and S.P.J. Batterbury (eds.). The geography of New Caledonia/Kanaky. Berlin/Heidelberg: Springer.

Saussol, A. 1988. The colonial chimera: from annexation to the re-emergence of Kanak identity. In M. Spencer, A. Ward and J. Connell (eds.). New Caledonia: essays in nationalism and dependency. St Lucia: University of Queensland Press. Pp. 38-55.

Scheiner, C. 2015. Can the Petroleum Fund exorcise the resource curse from Timor-Leste? In S. Ingram, L. Kent and A. McWilliam (eds.). A new era? Timor-Leste after the UN. Canberra: ANU Press. Pp. 73101. 
Sourisseau J.M., B. Geronimi and S. Bouard. 2016. La Nouvelle-Calédonie dans les turbulences du XXIe siècle. In S. Bouard, J.-M. Sourisseau, V. Geronimi, S. Blaise and L. Ro'i (eds.). La Nouvelle-Calédonie face à son destin: quel bilan à la veille de la consultation sur la pleine souveraineté? Paris: Karthala. Pp. 449-484.

Stastny, A. 2018. Le référendum pour l'indépendance de la Nouvelle-Calédonie ne consiste pas en un processus de décolonisation. Le Monde 1 November. Retrieved from: https://www.lemonde.fr/idees/article/2018/11/01/le-referendum-pour-l-independance-de-la-nouvellecaledonie-ne-consiste-pas-en-un-processus-de-decolonization_5377731_3232.html.

(UN) United Nations 2019. The United Nations and decolonization. Retrieved from: https://www.un.org/dppa/decolonization/en/nsgt

UNESCO 2020. Lagoons of New Caledonia: reef diversity and associated ecosystems. Retrieved from: https://whc.unesco.org/en/list/1115/.

Usher, M. 2019. Territory incognita. Progress in Human Geography. https://doi.org/10.1177/0309132519879492

Vivier, J.-L. 2009. Calédonie, l'heure des choix. Paris: L'Harmattan.

Waddell, E. 2008. Jean-Marie Tjibaou, Kanak witness to the world: an intellectual biography. Hawaii: University of Hawaii Press.

Winslow, D. 1995. Indépendance, savoir aborigène et environnement en Nouvelle-Calédonie. Journal of Political Ecology 2: 1-19. 